\title{
DIGITAL PHILANTHROPY: THE PRACTICE OF GIVING AMONG MIDDLE TO UPPER-CLASS MUSLIM IN INDONESIA AND SOFT CAPITALISM
}

\author{
Dony Arung Triantoro \\ State Islamic University of Sultan Syarif Kasim of Riau, Indonesia \\ arungdony73@gmail.com
}

\section{Tri Wahyuni}

State Islamic University of Sunan Kalijaga of Yogyakarta, Indonesia triewahuni46@gmail.com

\section{Fitra Prasapawidya Purna}

Muhammadiyah University of Yogyakarta, Indonesia fitra.prasapa93@gmail.com

\begin{abstract}
Academic discussions on transforming the culture of giving have shifted from direct assistance to long-term empowerment programs due to technology, communication, and informatics development. Therefore, this research aims to describe the practice of digital philanthropy in e-commerce and social enterprises. Data were collected from online-based e-commerce and social enterprise companies in Indonesia that have provided digital giving practice spaces through virtual ethnographic methods, interviews, and online documentation in Indonesia. These platforms include Bukalapak.com,
\end{abstract}


Tokopedia.com, Sedekahonline.com, and kitabisa.com. The results provide an overview to the Muslim community on the practice of digital philanthropy. In addition, this research also provides an overview of the importance of building partners and program campaigns for the digital financial services industry and Islamic philanthropic institutions.

Keywords: Islamic Philanthropy, E-Commerce, Social Enterprise, and Upper Middle-Class Muslims

\section{A. Introduction}

This research examines the practice of charity among upper-middle-class Muslims in the post-New Order in Indonesia. After the collapse of the New Order, significant changes were recorded in the way Muslims donate and manage Islamic social charities. The practice of charity such as zakat, alms, and others were initially carried out through mosque administrators or Modin (people in charge of managing mosques in rural Java such as the call to prayer, imam, etc). This also involved direct giving of infaq boxes in some mosques, a recent means of charity.

At the end of 1968, President Soeharto formed an Islamic philanthropic organization known as the Amil Zakat Agency (BAZ). This establishment was initially intended to support the development program promoted by the New Order using the potential of zakat and waqf funds. BAZ is widespread in big cities such as Jakarta, Central and East Java, and Yogyakarta. Presently, the practice of giving in urban Muslim communities has shifted to zakat institutions initiated by the government. However, it is realized in traditional societies through institutions, such as BAZ, which has received less attention. The traditional practice of giving direct aid to the poor and 
mosque administrators is still strong. It is an attribute that makes Islamic philanthropy one of the less successful state agenda programs. Although Soeharto failed to mobilize the practice of giving through the government's zakat institutions, in the 1980s, Soeharto founded the Pancasila Muslim Amal Bakti Foundation (YAMP). The founding of YAMP in 1982 seems to facilitate zakat practice for Muslim civil servants (PNS). Even though it was called a voluntary fund, the New Order government directly withdrew and reduced Muslim civil servants' monthly salaries until the end of Soeharto's regime (Latief, 2010).

Civil society movements that promoted Islamic giving multiplied during the transition from the New Order to the Reformation era. First, social charities initiated by mainstream Islamic organizations such as Muhammadiyah and Nahdlatul Ulama are actively involved in Islamic philanthropic activities (Latief, 2010). Furthermore, non-state zakat institutions such as Dompet Dhuafa, Dompet Peduli Rakyat Daarut Tauhid (DPU-DT), and Pos Keadilan Peduli Ummat (PKPU) started to actively respond to socio-economic issues of the Muslim community through the provision of social funds and other resources (Fauzia, 2016).

Recently, in the mid-2000s, the practice of giving is also carried out through such media due to the increase in the use of the internet (APJII survey, 2019). Therefore, it is presumed to be the new means of giving by the upper-middle-class Muslims in Indonesia. Many e-commerce platforms, such as Bukalapak.com, Tokopedia.com, BSI Mobile, Gojek, and social enterprises, namely Kitabisa.com and Sedekahonline.com, provide donation facilities.

The aforementioned statement shows the transformation of charity among the Muslim community. 
Meanwhile, whenever this issue is discussed, most scholars always emphasize shifting from the directassistance of thepoor to empowerment programs, such as Hilman Latief (2010) and Amelia Fauzia (2017). Latief analyzed the changing attitudes and orientations of Islamic philanthropic organizations. It was further reported that recent establishments no longer focused on programs that channel short-term direct social funds to the poor. However, they switched to a long-term empowerment scheme to eliminate poverty by providing training sessions, business capital, etc. This shift is in line with the discourse of bureaucratization and professionalization (Latief, 2010).

Similarly, Fauzia mapped out 3 forms of modernization carried out by Islamic philanthropic organizations since the Reformation era. These consist of legal, organizational management, and program reforms. Legal reform is related to the legality of zakat institutions that promotes them to work professionally and responsibly. Simultaneously, the second reform promotes philanthropic organizations to use the banking system, such as hiring professional staff, while maintaining transparency, and accountability, followed by program reformation (Fauzia, 2017). According to Latief (2010), Islamic philanthropic organizations need to expand their activities from providing direct assistance to the poor to initiating empowerment programs. In contrast to these studies, it was argued that the ability to transform the culture of giving among the Muslim community does not constantly shift to empowerment programs, but it also tends towards the direction of digital donation methods. Presently, the uppermiddle-class Muslim community donates their wealth directly or through digital programs oriented towards development and empowerment. 
Previous studies that focus on how digital media have become an essential part of a charity in Indonesia are evident in the works of Martin Slama (2017) and Najib Kailani \& Slama (2020). Furthermore, Slama discusses how social media has contributed to the lives of popular Indonesian preachers and aided in promoting their economic theological ideas (Slama, 2017). On the contrary, another research reported that internet use accelerates Islamic social charities. In addition, many philanthropists use social media to develop some form of closeness and trust among their donors. They massively distribute reports through the internet requesting Indonesian Muslims to provide social assistance for the underprivileged (Kailani \& Slama, 2020).

Makhrus (2018) stated that social media-based philanthropic communities such as Sedekah Rombongan, Laskar Sedekah, and Sedekah Kreatif Edukatif have proven to be a medium for donation and also a means of developing public awareness. In addition, the research carried out by Makhrus also reported that it is a means to build trust among philanthropists. This is consistent with Kailani and Slama's research, where it was reported that the philanthropic community accelerates these activities by uploading regular donation receipts on their website and social media (Makhrus, 2018).

Social media is a new means to collect donations and build trust between donors and the philanthropic community, as reported in the 2 research earlier mentioned. Aina Nurdiyanti and Karim Suryadi (2019) proved that a more inclusive means of public participation is achieved through digital philanthropy. They further explained how it paved the way for developing a civic culture, which includes 3 aspects, namely civic knowledge, skills, and disposition. 
Although the aforementioned studies focus on digital philanthropy, they do not highlight the practice in terms of e-commerce and social enterprise. Therefore, this research seeks to fill that void by examining the extent to which e-commerce and social enterprises provide online donation practices. In addition, it emphasizes the consequences of online giving practices that led to the term soft capitalism (Nigel Thrift, 2003). This is used to describe the concept that the practice of capitalism is not always related to calculative rationality but it is associated with social life and the continuous development of cultural circulation. Thrift emphasized the aspects of openness, contingency, and opportunity. Therefore, in respect to this research, soft capitalism is used to describe the economic opportunities created by e-commerce institutions through social activities such as online charity. The best illustration used to explain this is the research carried out by Eva F. Nisa (2018), which reported that Muslim women use Instagram to educate each other to be pious (da'wah). Da'wah activists also use social media platforms to promote their Islamic products in order to gain profit (lucrative). However, unlike Nisa, this research was photographed through digital philanthropy. In addition, it examines soft capitalism, which creates economic opportunities through social activities such as online charity.

Several Islamic philanthropic practices in fintech social enterprises and e-commerce, such as Bukalapak.com, Tokopedia.com, Go-Jek, Kitabisa.com, and Sedekahonline. com, were analyzed to obtain a comprehensive picture of the arguments in the aforementioned discussions. In addition, virtual ethnographic methods were used to analyze these platforms (Kozinet, 2010). Offline data presented during interviews with the program manager of the Sedekahonline. 
com Yogyakarta platform were also used to strengthen the online data. The limited access to leaders of several fintech platforms is the main reason for selecting only 1 Sedekahonline. com. Several fintech service users were interviewed to determine their experiences with online donation practices.

\section{B. Islamic Philanthropy in the New Media Development Landscape}

The increasingly significant development of the media has changed people's religious practices. Besides, it is used as a profane communication tool and perceived as a transcendental communication tool (Campbell, 2012). In respect to this, Campbell introduced the term digital religion, a practice free from its traditional patterns and projected in modern societal life. The media has offered a new socioreligious landscape concerning contemporary society.

Several terms are used to describe the increasingly significant development of the media. Some refer to it as the industrial revolution 4.0, while others call it the era of disruption (disruptive era). However, this refers to the theory of disruptive innovation initiated by Clayton M. Christensen. It also refers to all activities that led to creating new markets, values, and traditions (Christensen et al., 2015). Market actors are bound to have 2 different experiences during this era. First, some tend to be left behind and unable to survive with the new culture. Second, the others are bound to adapt to the new environment and become a significant players. This second group has recently initiated several economic sectors such as startups or financial technology (new digital-based companies that have emerged, although they have not been operating for a long time, have colored the many market) (Techinasia.com, 2015). 
In Indonesia, startup companies are beginning to multiply, besides, the Financial Services Authority (OJK), as well as the agent that oversees finance-related issues and pays attention to the growth of this technology (fintech) in the country, reported that from 2007 to 2016, these institutions have continued to increase. For example, in 2007, there were relatively 16 fintech institutions, while in 2016, there was an explosive increase to approximately 200 (Hadad, 2017). Moreover, companies that have recently become popular in urban communities are Go-Jek, Bukalapak.com, Tokopedia. com, etc. In addition, they have not only developed the economy, but also changed the consumption patterns and the peoples' religious practices.

Meanwhile, through these startup companies or fintech institutes, Islamic philanthropy has experienced significant development. In some scholarly discussions, it is known as Islamic charity (Kailani \& Slama, 2020) or financial worship (Benthall, 1999) related to zakat, alms, and waqf (Benthall, 1999; Kochuyt, 2009; Singer, 2013). In the Islamic religious tradition, zakat is divided into several aspects, such as zakat fitrah, Islamic charity activities in the form of distributing rice or money during the month of Ramadan, or zakat maal, which contributes $2.5 \%$ of Muslim assets and can be paid at any time. In contrast to zakat, which identifies the distribution of wealth, alms has a broader concept, which can be in the form of distributing material and non-material things such as smiles (Kailani \& Slama, 2020). Moreover, the distribution time is not tied, as is the case with zakat fitrah, and it can be given to anyone who needs help irrespective of the time.

Normatively, zakat is an act of virtue carried out by Muslims as the fulfillment of certain obligations under religious orders. However, sociologically its function is also 
perceived as an instrument of social welfare. During the New Order era, zakat was regarded as an essential instrument used to support development programs. Furthermore, Soeharto realized that zakat had good prospects in terms of supporting its policy and approved the establishment of a state institution, specifically for the collection of zakat funds called BAZ. Soeharto's policy was also supported by Muslim intellectuals that initiated the concept of "development preaching," which included teachings about the function and use of zakat funds for social welfare (Sakai, 2014). However, whether BAZ has played an optimal role in the appropriate use of these funds as an instrument of social welfare in the New Order era needs to be re-examined. The emergence of private zakat institutions such as Dompet Dhuafa, PKPU, and others shows that the state cannot distribute welfare to the community (Sakai, 2014; Wahyuni, 2019). However, this was not discussed in this research.

It is undeniable that Muslim intellectuals, such as Amin Rais and Masdar Farid, supported the New Order government's decision to make zakat an instrument of social welfare and justice. Amin Rais promoted the idea of professional zakat and proposed that it should not be issued at $2.5 \%$ of a person's income because everyone has a different income and profession (Retsikas, 2014). Conversely, Masdar Farid proposed that once an individual has paid the classical Islamic zakat, tax is unnecessary because they are similar (Retsikas, 2014).

In its development, along with the increase in middle and upper-class Muslims in Indonesia, Islamic philanthropy such as zakat and other societal charity types are articulated not only as a form of obligation, social welfare, or justice (Fauzia, 2017; Latief, 2010, 2012; Retsikas, 2014), but also as an instrument to boost prosperity (Kailani, 2015). In Kailani's 
dissertation, it was reported that the upper-middle-class Muslims applied the idea of economic theology. They compete in executing Islamic social charities such as alms, expecting that it returns to them multiplied. The idea of economic theology is also supported by popular preachers such as Yusuf Mansur, that the essence of almsgiving is to become prosperous in life (Kailani, 2015). According to Daromir Rudnyckyj (2010), these changes were driven by some Islamic actors in the media that introduced new discourses on the relevance of being pious to be prosperous.

The understanding of philanthropy is not the only concept that is constantly changing. The way collection and distribution of funds have also experienced significant developments. Traditionally, zakat is collected by mosque administrators or Modin, known as people responsible for taking care of mosques, including prayer sessions and other activities (Fauzia, 2013). Alms are usually dropped in charity boxes available at mosques, prayer rooms, or other public places. This view was later criticized by Islamic organizations, such as Muhammadiyah because it was argued that zakat needed to be managed professionally (Latief, 2010). Therefore, it needs to be bureaucratized or institutionalized in the Weberian tradition. This idea further strengthens the presence of ideal philanthropic institutions established by the state, such as BAZ, and private organizations such as Dompet Dhuafa, PKPU, Rumah Zakat, etc. Conversely, this does not mean that the idea of institutionalizing Islamic philanthropy is free from criticism. Mittermaier (2014) stated that the institutionalization of zakat tends to eliminate the donors' feelings. In addition, the bureaucratization of Islamic philanthropy is a lengthy process that requires registering the poor, followed by selecting and verifying whether they deserve to be assisted or not, which 
makes the concept of institutionalization slow in terms of responding to the needy. The institutionalization of Islamic philanthropy also requires additional costs due to the advantages and disadvantages of institutionalized philanthropy or charity in the form of direct assistance.

Recent developments show that the internet creates a new space for the zakat collection. Besides, many applications provide opportunities for donors to channel their wealth. These are initiated by social enterprise institutions such as Kitabisa. com and Sedekahonline.com, including e-commerce such as Bukalapak.com, Tokopedia.com, Go-Jek, etc. They provide donation spaces for upper-middle-class Indonesian Muslims.

The cultural transformation of giving, both in terms of Islamic philanthropy and the Muslim donation concept, is inseparable from the role of the middle and upper-class. Generally, in academic studies, the categories used to describe the middle class are based on 2 attributes, namely production and consumption (Dick, 1982; Heryanto, 2005; Robison, 1996; Smith-Hefner, 2020). For example, in terms of consumption, a person is assumed to be in the middle-class category, supposing they spend relatively USD 2 to 20 daily. Whereas in production, an individual who earns between USD 100 to 1000 per month is categorized as being in the middle class (Klinken, 2014). Heryanto (2005) stated that defining this class is difficult because of its social implications. For instance, those in this category that needs to be educated, reside in an urban area with a relatively good source of income, and socially occupy ideal positions such as intellectuals, managers, bureaucrats, or professionals in various fields. Conversely, Dick (1982) stated that those in the middle class are not always civil servants, professionals, intellectuals, entrepreneurs, journalists, pilots, etc. In Indonesia, they are determined by their lifestyle, assets, 
and the privatization of consumption tools for durable goods such as owning a motorcycle, car, television, refrigerator, cellphone, and other valuables.

In the 1980s, upper-middle-class Muslims played an important role in social and political landscapes. Initially, they originally emanated from the military that had close ties to Soeharto and businessmen and women facilitated by Golkar, the then ruling party. The Indonesian Muslim Intellectuals Association (ICMI) tended to be apolitical. Meanwhile, the upper-middle-class was actively involved in responding to societal issues in the social aspect. Since the economic crisis that occurred in the late 1990s, upper-middle-class Muslims have played a significant role in the practice of almsgiving. Its impact left a large part of the low-income community in dire severe straits and increased unemployment. This issue promoted upper-middle-class Muslims to embrace the culture of giving in accordance with religious tendencies.

In the beginning of the Reformation era, there was increased bureaucratization and professionalization of Islamic philanthropy. This was also a welcome development based on the role of upper-middle-class Muslims due to their educational background and applied knowledge in reforming the poorly organized culture of giving. Many philanthropic organizations adopted a banking management system and recruited professionals (Latief, 2010). Additionally, Jonathan Benthall (1999) stated that in the Koran, Muslims reinterpreted zakat in Jordan and other countries.

In 1999, President Habibie implemented the Zakat Law, which led to establishing government-sponsored and community-based institutions such as BAZ and LAZ, respectively (Latief, 2010). Finally, many philanthropic organizations have used digital media to raise funds for charity 
in recent years, besides this was initiated by upper-middleclass Muslims. These digital devices and other social charities target this category of people because they usually have little free time. In addition, they tend to spend more time working in offices, enjoying their vacation, eating in restaurants and Malls, and being familiar with their smartphones (Heryanto, 2005). Therefore, Digital philanthropy, whether in e-commerce or social enterprise, makes it easier for middle and upperclass Muslims to channel their wealth. The following section discusses digital philanthropy with respect to e-commerce and social enterprise.

\section{Digital Philanthropy in E-Commerce: Bukalapak.com, Tokopedia.com, and Go-Jek}

The increasingly significant development of the internet has changed the interactive pattern of a global society. In Indonesia, for example, after the New Order, control over mass media weakened, thereby enabling people to have free and easy access to some political, economic, social, cultural, and even entertainment information. In addition, television provides religious broadcasts which enable viewers (television communities) to choose the program that best suits their preferences. According to Inaya Rakhmani (2016), it has recently become a propaganda supermarket (supermarket dakwah).

In the early 2000s, social media became viral among Indonesians besides televisions and radios, evidenced by its increasing usage (APJII, 2019). Those in the upper-middleclass society actively use various applications such as Whatsapp, E-mail, Line, and Facebook to interact. In addition, they enjoy photos and entertainment videos uploaded on Instagram, Youtube, etc., during leisure. 
With the increasing use of the internet among this category of people, startup companies such as e-commerce that appreciate social media culture have also emerged. They offer new patterns to meet the daily needs of this category, such as online shopping. Presently, approximately 20 e-commerce companies dominate the indigenous market, including those initiated by foreign business actors such as Lazada, Shopee, and Zolora, and the nation's products, namely Bukalapak and Tokopedia (Iprice.co.id, 2020). It also coincides with the increasing number of users in the country. In 2017, e-commerce users reached 139 million, and in 2019, it rose by $10.8 \%$ to reach approximately 154.1 million. Jayani (2019) predicted that by 2023, 212.2 million users are bound to be recorded.

This research focuses on e-commerce Bukalapak.com, Tokopedia.com, and Go-Jek. These 3 platforms do not only provide online shopping services for the upper-middle-class community, it also accommodates their religious spirit as indicated by their social charity features, such as donations and zakat, as shown in Figure 1.

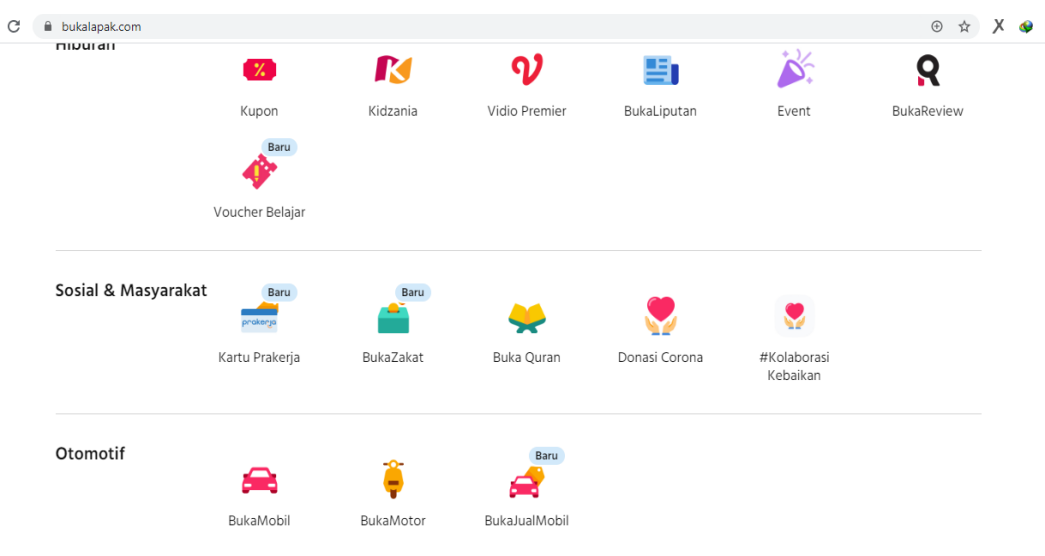

Figure 1: Office site Zakat on Bukalapak.com (Source: Bukalapak.com website) 


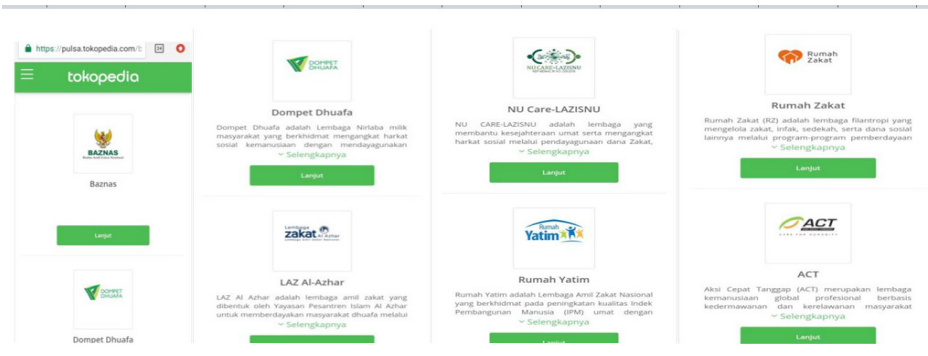

Figure 2: Office site Zakat on Tokopedia.com (Source: Tokopedia.com website)

Figures 1 and 2 show that recent Islamic philanthropic activities occur in traditional forms and utilize e-commerce applications, such as Bukalapak.com and Tokopedia.com. Bukalapak.com has zakat payment features and digital donations in collaboration with six philanthropic institutions, both initiated by the government, such as BAZNAS and the private ones, namely Dompet Dhuafa, Rumah Zakat, LAZISNU, LAZISMU, and Zakat Center for people. Since its emergence, the execution of digital philanthropy on this platform has continued to increase, both in terms of users and in obtaining donations. According to the CEO of Bukalapak.com, Rachmat Kaimuddin stated, "The growth of zakat in Bukalapak is over $70 \%$, with a total receipts of billions of rupiah to this day" (Annur, 2020).

Tokopedia.com is another example of e-commerce that provides a digital donation space. This platform is slightly different from Bukalapak.com, although it also provides online zakat service features. On the contrary, they are distinguished by the partners that collect zakat funds. Tokopedia has more partners, besides, it collaborates with 8 philanthropic institutions, such as BAZNAS, Dompet Dhuafa, Rumah Yatim, Rumah Zakat, Al-Azhar, NU Care-LAZISNU, LAZISMU, and the 
Indonesian Zakat Initiative (IZI). Based on an online report released by Tokopedia on July 7, 2021, the amount of zakat collected as of May 22, 2020, is Rp. 3.060.135.000 with a total of 26.673 donors (Tokopedia.com, 2020).

Recently, digital philanthropy has also been found in online transportation fintech such as Go-Jek. This is one of the most extensive online transportation services in the country that has changed the mobility of the wider community. GoJek also offers other services such as Go-Food (online food delivery service), Go-Send (goods delivery service), GoPulsa (online credit purchase service), and Go-Mart (grocery delivery service). In addition, the payment models are also diverse as consumers pay service fees directly using cash or through Go-Pay, an electronic money system that facilitates certain transactions, including the buying and selling of goods and services.

Meanwhile, one of the new features developed by GoJek is zakat, and through this application, people can easily engage in works of charity. Before issuing the official zakat site, Go-Jek first initiated the donation method with the official Go-Bill and zakat barcode or QR code at every mosque that has collaborated with Go-Jek to donate directly through Go-Pay by simply scanning the code. In addition, printed QR was quickly entered into the mosque's account. 


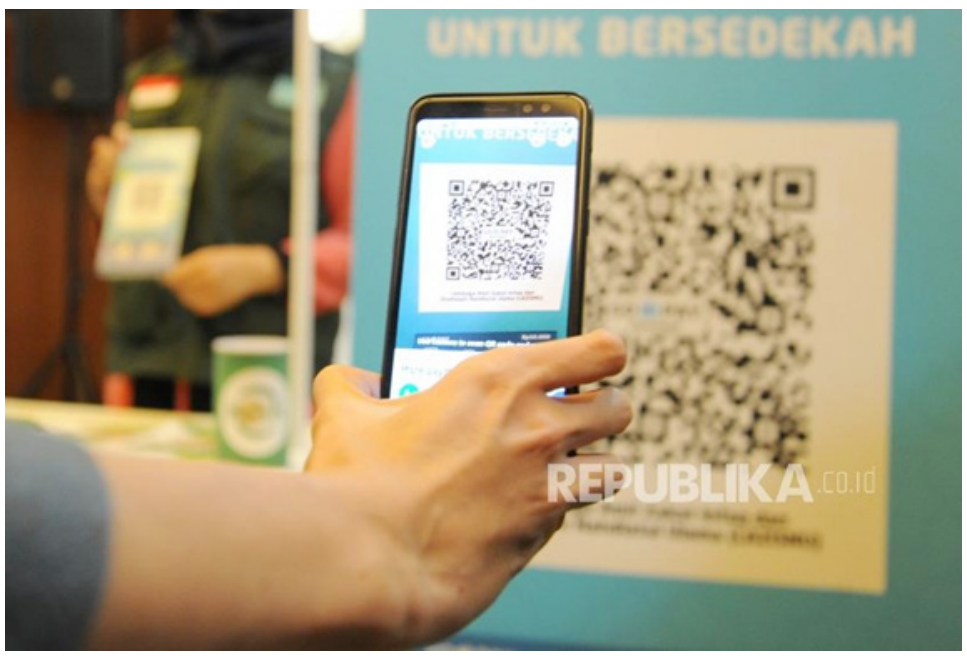

Figure 3: QR Barcode for non-cash payment of zakat, infaq, and alms through Go-Pay (Source: Republika.com)

The community appreciated this feature, besides, throughout 2019, digital donations using GoPay increased 11 times. Interestingly, over Rp. 82 billion donations collected through this platform have been distributed to more than 400 non-profit organizations in 21 provinces throughout Indonesia that have partnered with this institute for Good digital donation program (Gatra.com, 2020). In 2020, Go-Jek noted that donation transactions carried out on its platform had increased compared to the previous year. Based on GoPay data, this was presumed to be increased by 2.5 times, with total digital donations reaching Rp. 136 billion (Wardani, 2021). One of the factors that boosted this increase in 2020 was the Covid-19 pandemic that hit the world, including Indonesia, thereby limiting the offline space. This condition, in turn, forced people to carry out online transactions, including the practice of giving. 
There is no significant difference between the official zakat site on Go-Jek and other e-commerce digital philanthropic service features such as Tokopedia.com and Bukalapak.com. Similar to the two previously mentioned e-commerce platforms (Tokopedia and Bukalapak), Go-Jek also collaborated with the philanthropic institutions such as BAZNAS, Baitul Maal Hidayatullah, LAZISMU, LAZISNU, Rumah Yatim, Dompet Dhuafa, Global Zakat, ACT, and Rumah Zakat. However, Go-Jek partnered with more philanthropic institutions than the two previously mentioned e-commerce platforms, Bukalapak.com and Tokopedia.com. It has been proven that several partners collected zakat funds in e-commerce, thereby negatively affecting the high amount of digital donation revenue, as shown in Table 1.

Table 1. Number of Partners and Donation Revenue in E-Commerce

\begin{tabular}{ccccc}
\hline No. & E-Commerce & $\begin{array}{c}\text { Number of } \\
\text { Partners }\end{array}$ & Income & Year \\
\hline 1. & Tokopedia & 8 & Rp. 3,060,135,000 & 2020 \\
\hline 2. & Bukalapak & 6 & No exact data & 2020 \\
\hline 3. & Go-Jek & 9 & Rp. 136,000,000,000 & 2020 \\
\hline
\end{tabular}

The data in Table 1 shows that Go-Jek, which has more partners than Bukalapak.com and Tokopedia.com, has a higher donation income. Meanwhile, Tokopedia.com, which has 8 philanthropic partners, received lower donations. Unfortunately, there was no exact donation data for Bukalapak and from comparative analysis relating to the number of partners it is presumed to be lower than Tokopedia and needs to be further explored.

In addition, the data relating to the growth of zakat funds through several e-commerce illustrates the practice 
of giving, which has begun to shift from the traditional to digital ways. At the same time, it also shows that the relationship between Islam and business are simultaneous. The new management concept initiated by e-commerce to gain profit while accommodating the Muslim community's social and religious cultures is referred to as soft capitalism (Nigel Thrift, 2003). In addition to promoting the importance and advantages of giving through digital spaces, they also benefitted from visitors or users of their website. Nisa (2018) refers to this lucrative practice as da'wah (profitable da'wah).

\section{Digital Philanthropy in Social Enterprise: Sedekahonline.com and Kitabisa.com}

E-commerce is not a startup firm (digital company) that focuses on raising funds for charity, but it is a digital establishment engaged in business activities looking forward for profit. Meanwhile, Social Enterprise is an application created to serve people that intend to channel their funds to the need. It also provides opportunities for underprivileged communities to get assistance from donors through campaigns based on internet technology, especially on websites and mobile applications.

Kitabisa.com and Sedekahonline.com are examples of popular social enterprises in Indonesia. This establishment is engaged in social actions, specifically fundraising, which have migrated from the conventional methods to online. The social enterprise prioritizes funds' transparency during collection and distribution. This enables donors to be able to monitor the entire process.

Kitabisa.com and Sedekahonline.com possess certain similarities and differences. Kitabisa.com, for example, is not 
a social enterprise that is limited to Islam, however, it also accepts donations from other religions such as Christianity, Hinduism, and Buddhism. Meanwhile, Sedekahonline.com is a social enterprise associated with Islamic philanthropy, however, both of them promote social charity fundraising. Kitabisa.com has 10 categories of social distribution, namely medical and health assistance, sick toddlers and children, humanity, natural disasters, houses of worship, social activities, zakat, scholarships, education, and other assistance. In addition, Kitabisa.com has approximately 100 Islamic philanthropic campaigns running on its website. These are divided into programs with approximately 90 days and unlimited (permanent) running time limit. These are usually carried out in collaboration with Kitabisa.com and large philanthropic institutions such as BAZNAS, Dompet Dhuafa, Rumah Zakat, Global Zakat, etc.

Each program has a different donor absorption capacity, and it is influenced by philanthropists that design creative campaigns to attract donors. Even though as a social enterprise, Kitabisa.com also gets $5 \%$ income or profit from each program broadcast (Hidayat, 2019). On June 24, 2021, acquiring funds from 100 campaigns that aired on kitabisa. com was relatively Rp.102.952.222.390 with 3,166,187 donors and 70 partners (Kitabisa.com, 2020). The western management capitalism pattern still influences similar social businesses. This is referred to as soft capitalism or the meeting between western management and profitable Islamic charitable practices. 


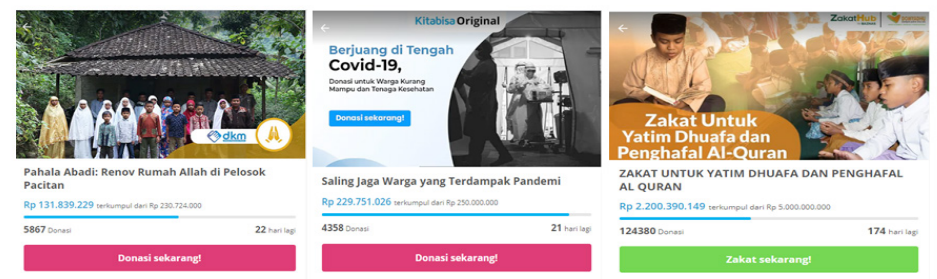

Figure 4: Program Campaign Poster on Kitabisa.com (Source: Kitabisa.com website)

In contrast to Kitabisa.com, Sedekahonline.com is highly focused on Islamic philanthropic activities. Interestingly, under the control of the Darul Quran Foundation or PPPA Daqu, this platform is inseparable from Ustaz Yusuf Mansur, a famous preacher in Indonesia that often promotes the virtue of alms. According to Maulana, the manager of Sedekahonline. com, he stated:

"The Sedekahonline domain was created to make it easier for muzakki throughout the country to pay zakat more transparently as well as to be able to select the donations for specific programs. Therefore, it is hoped that this internet-based method of collecting philanthropic funds is developed under a wider empowerment scheme." (Interview with Maulana, September 2019).

Sedekahonline.com uses its digital donation method through social charity campaigns (Figure 5) such as Kitabisa. com to raise funds. Until June 25, 2021, it received donations of approximately Rp. 1.335.480.539 in accordance with 75 Islamic philanthropic campaigns and 6 partners, namely the Sahabat Qu Islamic Boarding School, Humaira Taklim Council, Amanah Santri House, Tahfidz Al-Islam House, Tahfidz Bangunjiwo House, and Nur Hidayat Imogiri Hospital. 


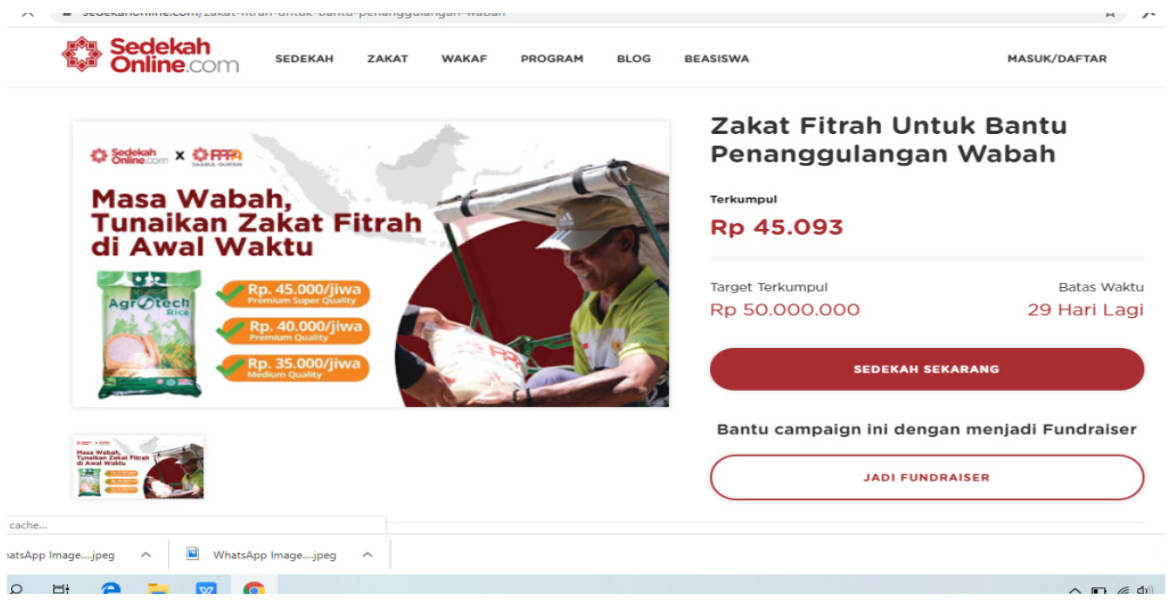

Figure 5: One of the Zakat Campaigns in the Month of Ramadan (Source: Sedekahonline.com website)

The aforementioned explanation is similar to Islamic philanthropy based on e-commerce. The number of partners is the main factor that contributes to the donations made, as shown in Table 2

Table 2. Number of Partners, Program Campaigns and Revenue Donations in Social Enterprise

\begin{tabular}{clcccc}
\hline No. & Social Enterprise & $\begin{array}{c}\text { Number of } \\
\text { Partners }\end{array}$ & $\begin{array}{c}\text { Program } \\
\text { Campaign }\end{array}$ & Income & Year \\
\hline 1. & Kitabisa.com & 70 & 100 & Rp. 102.952.222.390 & 2021 \\
\hline 2. & Sedekahonline.com & 6 & 75 & Rp. 1.335.480.539 & 2021 \\
\hline
\end{tabular}

Kitabisa.com has 70 partners, while Sedekahonline.com only has 6 . In addition, from the campaign program aspect, it is higher than Sedekahonline.com. Kitabisa.com displays 100 program campaigns, while the other platform exhibits 75 , which shows the importance of cooperation and promotion. 


\section{E. Giving through E-Commerce and Social Enterprise:}

\section{Pure Giving, Special Programs, and Continuous Piety}

In principle, there is not much difference in donations made through e-commerce such as Bukalapak.com, Tokopedia. com, and Go-Jek. However, donors are attracted in diverse ways. Bukalapak.com, in addition to displaying the official sites of zakat institutions such as BAZNAS, Dompet Duafa, and others, also has an exciting donation method realized through the "Serbu Seru" program.

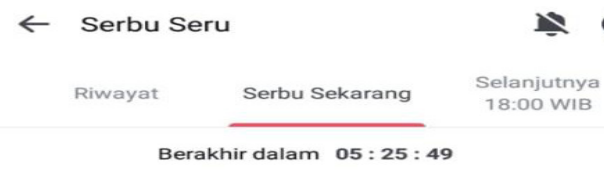

Berakhir dalam $05: 25: 49$
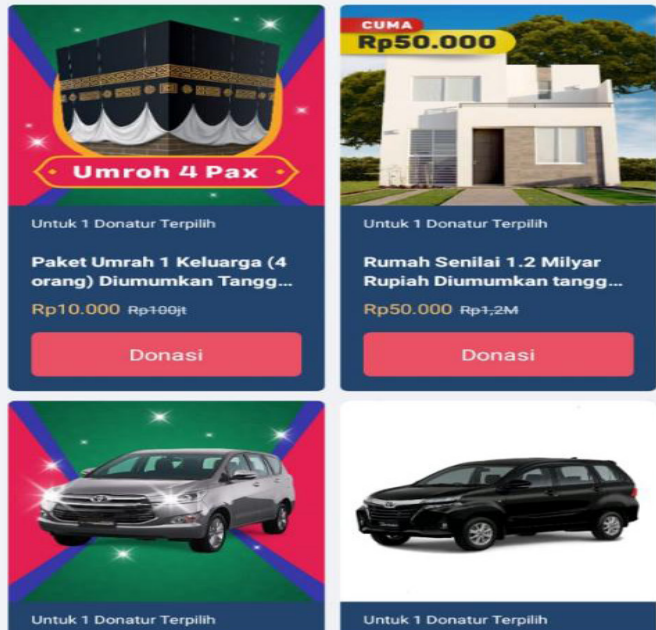

Figure 6: Bukalapak.com Exciting Assault Program (Source: Bukalapak.com Official Site)

This new method is considered unique because Bukalapak.com applies a donation system similar to a "raffle draw" with prizes to be won under certain conditions. Meanwhile, through this program, donors not only have the opportunity to get luxury goods such as cars, gold, cellphones, Umrah packages, and houses, they are also able 
to make donations. Furthermore, Bukalapak.com users who have been registered tend to quickly join the "Serbu Seru" program, which offers a variety of prizes by only spending little or nothing. For example, the "1 Billion Home Assault" program opened an account for paying only $\mathrm{Rp} 50.000$ to certain philanthropic institutions.

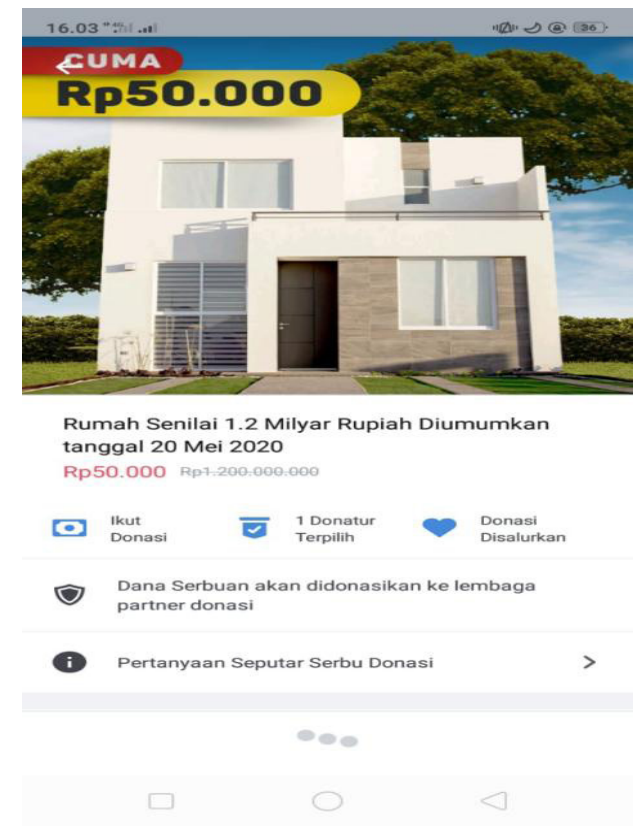

Figure 7: The 1 Billion Home Assault Program on Bukalapak.com (Source: Bukalapak.com Official Site)

Unlike the general amount spent on buying the sweepstakes, which tends to be lost, in this "Serbu Seru" program, Bukalapak.com guarantees to return the user's money, supposing they do not get the raid. However, the refund is not in the form of cash, but it is in the form of valuable donations to philanthropic institutions which names have been included in the exciting assault program or several other returns. 
Bukalapak.com also provides a general donation space such e-commerce. For example, donors are allowed to select which institution they intend to donate to, enter its worth, and finally select a payment method, as shown in Figure 8. This method is directed towards absolute philanthropy with the sole purpose of paying tithe or charity. It is different from the previous "Serbu Seru" program, which featured 2 attributes, namely shopping and giving. A member of the "Serbu Seru" program stated that it facilitates the aspirations of middle and upper-class Muslims that intend to improve their welfare as well as appear pious. Fanny Arumsari (27 years old), and informants, further stated that donations made through Bukalapak.com vary. This experience was shared during digital donation due to leftovers from shopping online.

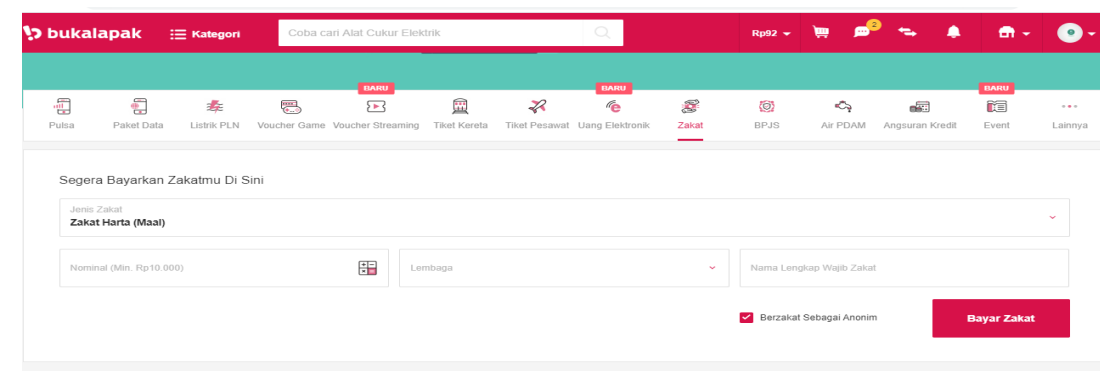

Figure 8: Pay Zakat through Bukalapak.com (Source: Pay Zakat Official Site Bukalapak.com)

Similar to the pure donation method adopted by Bukalapak.com, Tokopedia.com also has an official site, specifically for this practice. Its visitors tend to click on the donation menu to select which philanthropic institution to channel their funds. Meanwhile, several of them such as the Joint Venture for Sharing (Patungan Untuk Berbagi), Dompet Dhuafa, BAZNAS, Rumah Zakat, Rumah Yatim, LAZISNU, WeCare.id, etc are available on the official donation site. After the visitor selects a philanthropic institution, the following 
step is to choose the amount to be donated. As far as this search goes, donations range from Rp.10.000 to Rp.1.000.000. Each philanthropic organization has a limit regarding their respective donations. The donations made through BAZNAS, Rumah Zakat and the Joint Venture for Shari ranges from Rp. 10.000 to Rp. 1.000 .000 , Rp. 25.000 to Rp. 1.000 .000 and Rp. 99.000 to Rp. 891.000. After the visitor has selected the intended donation, the following step is to choose a payment method such as through credit card, ATM, transfer, or even through supermarkets such as Alfamart, etc.

In accordance with the previous informant, the following one, named Tsabita Nur Afifah (22 years old), reported their experiences making a digital donation through Tokopedia. com. Similarly, Fanny and Tsabita also donated because there was leftover money online shopping through Tokopedia. com. One interesting comment was that digital donation does not convey a sense of compassion because the object being donated is not directly visible. Tsabita's argument supports Amira Mittermaier's (2014) research which discusses the generosity community in Egypt.

Digital philanthropic institutions based on social enterprises such as Sedekahonline.com and Kitabisa.com are focused on collecting zakat, alms, and other forms of charities. Therefore, the display of website features also tends to be easier to use than e-commerce-based digital philanthropic platforms such as Tokopedia.com, Bukalapak.com, and Go-Jek. Social enterprise-based digital philanthropy does not engage in business or market activities. Interestingly, they focus only on social fundraising efforts. For example, when the websites of certain platforms, such as Kitabisa.com, are opened, visitors are faced with several menus such as zakat, Kita Bisa plus, and regular donations. The latest development of this 
menu has changed to that of donations, zakat, mutual care, and fundraising, with each having a different orientation. The donation menu, for example, is used for donors who intend to donate their wealth to specific programs such as alms for Santri Memorizing the Qur'an, Mosque Construction, Land Waqf, Alms for Mosque Facilities, Assistance for Orphans, etc. Then lastly, the zakat menu is used by Muslims who intend to distribute their zakat funds. Meanwhile, when users click on this menu, they are faced with several zakat institutions such as BAZNAS, Rumah Yatim, Dompet Dhuafa, etc.

In addition to the 2 previously mentioned menus, namely donation and zakat, Kitabisa.com has added several new ones, including the Kitabisa Plus menu. This is used to help Indonesians affected by the Covid-19 pandemic, a recent contagious outbreak in various countries worldwide. The Kitabisa Plus program facilitates donors who desire to help out in health-related matters. However, this program is only valid during the emergency period as determined by the government from April 1 to May 31, 2020.
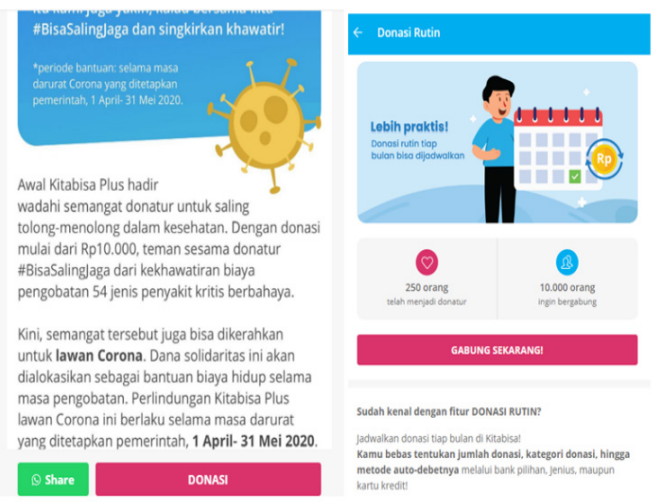

Figure 9: Kitabisa Plus Program Poster and Regular Donations

(Source: https://plus.kitabisa.com/and https://kitabisa.com/donasi-rutin/register) 
The Routine Donation Program is also one of the new initiatives provided by Kitabisa.com and Kitabisa Plus. It is carried out every month according to the donation schedule set by Kitabisa.com. In this program, donors do not need to transfer their donations multiple times because the payment system is auto-debit realized through the selected bank. Donors tend to select their donation category and preferred bank used for payment. Therefore, the bank automatically deducts the donor's account balance every month, and it is referred to as continuous piety in the practice of giving. By joining this program, donors practically engage in social charity every month. Regarding this program, Kitabisa. com even builds an argument centered on the fact that this program anticipates people's neglect to donate. As of May 27,2020 , this program has been attended by 250 donors and 10.000 other people intented to join the initiative.

Donors tend to receive the regular donation program, for example, on the Kitabisa.com website, a donor named Erma Hermawati reported joining the regular initiative due to difficulties. Meanwhile, another donor, Ulfa, an IDN Media journalist, stated that donations were made because it was believed to be replaced and multiplied by Allah SWT. It follows the economic theology of gift-giving initiated by Marcel Mauss, which explains anything given is bound to be rewarded in the after life. Therefore, the gift does not necessarily disappear, but it tends to be developed (Mauss, 2002). This concept is also often echoed by Islamic preachers in the country, such as Ustaz Yusuf Mansur, who often quotes a verse in the Qur'an (Al-Baqarah: 261), which explains that almsgiving is such planting a seed. Each grain grows 7 stalks worth a hundred (Kailani, 2015).

Unlike the experiences of previous informants who executed digital donations through e-commerce because there 
was some leftover cash from their shopping activities, another informant, named Ellen, a 28-year-old entrepreneur, stated that digital donations made through Kitabisa.com were strictly for charity. As mentioned earlier, a social enterprise is not an institution engaged in e-commerce, therefore, there is no need to shop on this platform. Besides, the practice of giving through social enterprise is presumed to be purely charity.

Another social enterprise institution, namely Sedekahonline.com, was initiated by Ustaz Yusuf Mansur, under the auspices of PPPA Darul Quran, an Islamic boarding school for memorizing the Koran, situated in Tangerang City, Jakarta. Sedekahonline has a different focus on the distribution of donations from Kitabisa.com. The majority of its programs are focused on everything related to the empowerment of the Qur'an, such as the Tahfidz House Roof Repair Program, Assistance for Blind Al-Quran Memorizing, Construction of Recitation Rooms, Electricity Procurement for Saung Tahfidz, etc. However, in a minute aspect, Sedekahonline.com also responds to other social problems such as Direct Assistance for the Poor, Basic Food Assistance, Assistance for Disabilities Equipment, Health Assistance, etc.

Meanwhile, during the creation of the Sedekahonline. com site, visitors face several donation menu displays such as alms, zakat, and waqf. They enter their donation, full name, mobile number, e-mail, and payment method. However, there is something that distinguishes Sedekahonline.com from other digital philanthropic institutions, both based on e-commerce and social enterprises. In the alms, zakat, and waqf menus, for example, donors not only fill in their identity, donation amount, and payment method but are also given a particular column, where they tend to offer prayers regarding the program initiated by Sedekahonline.com. 


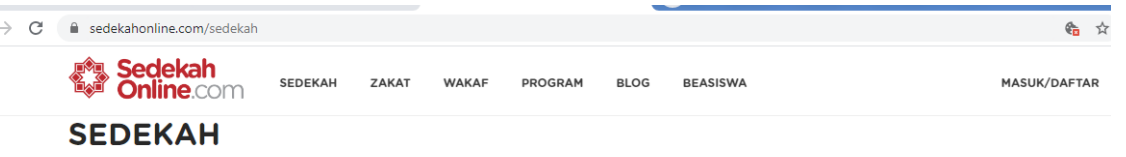

"Kamu sekall-kall tıdak sampal kepada kebajkkan (yang sempurna), sebelum kamu menarkahkan sehahaglan harta yang kamu cintai. Dan apa saja yang kamu narkahkan, maka sesungguhnya Allah mengetahuinya" (QS. Ali Imran/3: 92)
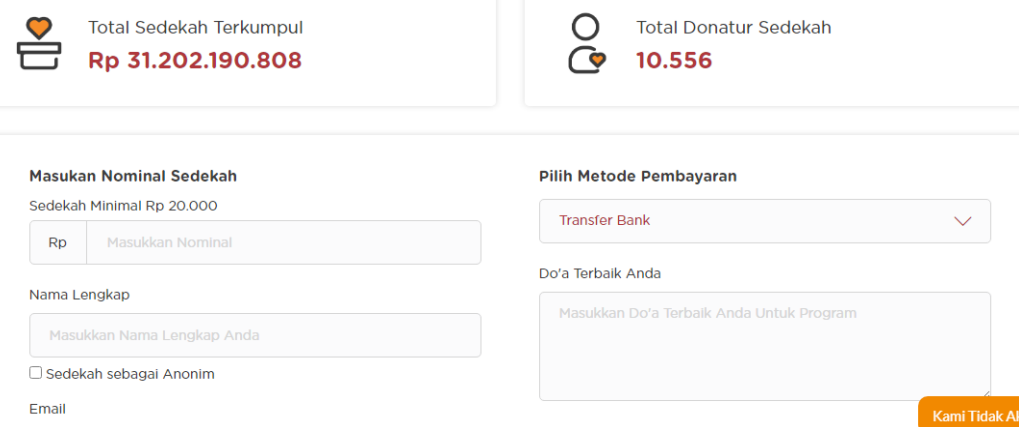

Figure 10: Display of the Alms Menu on sedekahonline.com (Source: https://sedekahonline.com/sedekah)

Sedekahonline.com also reports the number of donations made and the number of donors on the menus. However, instead of reporting massively on these attributes, this platform also promotes the idea of social charity by quoting 1 of the verses in the Qur'an, namely Surah Ali-Imran verse 92, which says, "Times do not reach the (perfect) virtue before part of the wealth loved is spent. Moreover, Allah indeed knows about anything that is spent".

\section{F. Conclusion}

This research has proven that recently, there has been a shift in the promotion of Islamic social charity or philanthropy in Indonesia. In addition, this practice is no longer carried out traditionally, and it is performed through digital cultural means. This shift is influenced by the increasingly significant development of internet media and the growth of uppermiddle-class Muslims in the country. Some e-commerce outlets 
such as Bukalapak.com and Tokopedia.com have collaborated with Islamic philanthropic institutions such as BAZNAS, Dompet Dhuafa, ACT, Rumah Zakat, LAZISMU, LAZISNU, etc to provide digital donation services. In addition to e-commerce, fintech social enterprises also provide digital philanthropic features. This is evident in social enterprises such as Kitabisa. com and Sedekahonline.com. Online transportation service companies, such as Go-Jek also provide digital philanthropy features (Go-Zakat). This is realized through the collaboration between fintech companies and philanthropic institutions. Therefore, it was concluded that Islam and business (capitalism) are intertwined, this is also referred to as soft capitalism by Nigel Thrift.

The number of partners and program campaigns is one of the crucial factors in digital donations. It is evident in the results of this research which shows that digital philanthropic institutions, both e-commerce and social enterprises, which have partners and program campaigns, get more donations. Finally, this research provides an overview of the practice of digital giving to the Muslim community. The digital financial services industry (fintech) provides input on the importance of partnering (cooperation) with several Islamic philanthropic institutions. This helps to consider the importance of massive program campaigns in digital spaces. Therefore, for policymakers, this research tends to consider the implementation of policies concerning the importance of re-conceptualizing Islamic philanthropy from conventional methods to digital philanthropy. 


\section{REFERENCES}

Annur, C. M. (2020). Bayar Zakat via Bukalapak, Shopee, Gojek Naikhingga 100\%saatRamadan.Katadata.Co.Id.https:// katadata.co.id/desysetyowati/digital/5ec4c69aa9 bec/ bayar-zakat-via-bukalapak-shopee-gojek-naik-hingga100-saat-ramadan

APJII. (2019). Laporan Survei dan Profil Perilaku Pengguna Internet Indonesia Tahun 2018. https://www.apjii.or.id/ survei.

Benthall, J. (1999). Financial Worship : The Quranic Injunction to Almsgiving. The Journal of the Royal Anthropological Institute, 5(1), 27-42. https://doi.org/https://doi. org/10.2307/2660961

Campbell, H. (2012). Digital religion: Understanding religious practice in new media worlds. Routledge.

Christensen, C. M., Raynor, M. E., Rory, M., \& McDonald, R. (2015). What is disruptive innovation? Harvard Business Review, 93(12), 44-53. https://hbr.org/2015/12/whatis-disruptive-innovation

Dick, H. W. (1982). The Rise of a Middle Class and the Changing Concept of Equity in Indonesia: An Interpretation. Indonesia, 39, 71-92. https://doi.org/https://doi. org/10.2307/3350987

Fauzia, A. (2013). Faith and the State: A History of Islamic Philanthropy in Indonesia (M. Ricklefs \& B. Lockhart (eds.)). Brill.

Fauzia, A. (2016). Filantropi Islam: Sejarah dan Kontestasi Masyarakat Sipil dan Negara. Penerbit Gading.

Fauzia, A. (2017). Islamic philanthropy in Indonesia: Modernization, islamization, and social justice. Austrian 
Journal of South-East Asian Studies, 10(2), 223-236. https://doi.org/10.14764/10.ASEAS-2017.2-6

Gatra.com. (2020). Bayar Zakat Digital, GoPay Gandeng Tiga LAZ Baru. Gatra.Com. https://www.gatra.com/detail/ news /468300/ekonomi/bayar-zakat-digital-gopaygandeng-tiga-laz-baru

Hadad, M. (2017). Financial Technology (FinTech) di Indonesia. Fintech-IBS, OJK Jakarta.

Heryanto, A. (2005). The years of living luxuriously: identity politics of Indonesia's new rich. In M. Pinches (Ed.), Culture and privilege in capitalist Asia (pp. 160-188). Routledge.

Hidayat, A. A. A. (2019). Platform Donasi Online dan Filantropi Digital (Kajian Aktivitas Filantropi dan Komodifikasi Kampanye Sosial melalui Kitabisa.com). Universitas Airlangga.

Iprice.co.id.(2020).PetaE-CommerceIndonesia.Iprice Insights. https://iprice.co.id/insights/mapofecommerce/

Jayani, D. H. (2019). Tren Pengguna E-Commerce Terus Tumbuh. Databoks. https://databoks.katadata. co.id/datapublish/2019/10/10/tren-pengguna-ecommerce-2017-2023

Kailani, N. (2015). Aspiring to Prosperity: the Economic Theology of Urban Muslims in Contemporary Indonesia. University of New South Wales.

Kailani, N., \& Slama, M. (2020). Accelerating Islamic charities in Indonesia: zakat, sedekah and the immediacy of social media. South East Asia Research, 28(1), 70-86. https:// doi.org/10.1080/0967828X.2019.1691939 
Kitabisa.com. (2020). Donasi Rutin. Kitabisa.Com. https:// kitabisa.com/donasi-rutin/register

Klinken, G. Van. (2014). Introduction: Democracy, Markets, and the Assertive Middle. In G. Van Klinken \& W. Berenschot (Eds.), In Search of Middle Indonesia: Middle Classes in Provincial Towns (pp. 1-32). Brill.

Kochuyt, T. (2009). God, gifts and poor people: On charity in Islam. Social Compass, 56(1), 98-116. https://doi. org/10.1177/0037768608100345

Kozinet, R. V. (2010). Netnography: Ethnographic research in the age of the internet (1st ed.). SAGE Publications.

Latief, H. (2010a). Health provision for the poor: Islamic aid and the rise of charitable clinics in Indonesia. South East Asia Research, 18(3), 503-553. https://doi. org/10.5367/sear.2010.0004

Latief, H. (2010b). Melayani Umat: Filantropi Islam dan Ideologi Kesejahteraan Kaum Modernis. Gramedia Pustaka Utama.

Latief, H. (2010c). Transforming the Culture of Giving in Indonesia: The Muslim Middle Class, Crisis and Philanthropy. Nanzan University Asia-Pacific Research Center, 11(11), 1-21.

Latief, H. (2012). Islamic Charities and Social Activism: Welfare, Dakwah and Politics in Indonesia. Utrecht University.

Makhrus, M. (2018). Social Media Based Islamic Philanthropy To Develop Philanthropy Awareness In Indonesia. Advances in Social Science, Education and Humanities Research, 231(Amca), 365-368. https://doi. org/10.2991/amca-18.2018.100

Mauss, M. (2002). The gift: The form and reason for exchange in archaic societies. In The Gift: The Form and Reason for 
Exchange in Archaic Societies. Routledge. https://doi. org/10.4324/9781912281008

Mittermaier, A. (2014). Beyond compassion: Islamic voluntarism in Egypt. American Ethnologist, 41(3), 518531. https://doi.org/10.1111/amet.12092

Nisa, E. F. (2018). Creative and Lucrative Dawa: The Visual Culture of Instagram amongst Female Muslim Youth in Indonesia. Asiascape: Digital Asia, 5(1-2), 68-89. https://doi.org/10.1163/22142312-12340085

Nurdiyanti, A., \& Suryadi, K. (2019). Digital Philanthropy in Indonesia: Strengthening Civic Virtue for Digital Citizens. Advances in Social Science, Education and Humanities Research, 317(IConProCS), 139-143. https://doi. org/10.2991/iconprocs-19.2019.28

Rakhmani, I. (2016). Mainstreaming Islam in Indonesia: Television, Identity, and the Middle Class. Palgrave Macmillan.

Retsikas, K. (2014). Reconceptualising Zakat in Indonesia: orship, philanthropy and rights. Indonesia and the Malay World, 42(124), 337-357. https://doi.org/10.1080/13 639811.2014 .951519

Robison, R. (1996). The middle class and the bourgeoisie in Indonesia. In R. Robison \& D. S. G. Goodman (Eds.), The New Rich in Asia: Mobile phones, McDonald's and middleclass revolution (pp. 79-104). Routledge.

Rudnyckyj, D. (2010). Spiritual Economies: Islam, Globalization, and the Afterlife of Development. Cornell University Press.

Sakai, M. (2014). Establishing social justice through financial inclusivity: Islamic propagation by Islamic savings and credit cooperatives in Indonesia. TRaNS: Trans-Regional and -National Studies of Southeast Asia, 2(2), 201-222. https://doi.org/10.1017/trn.2014.4 
Singer, A. (2013). Giving Practices in Islamic Societies. An International Quarterly, 80(2), 341-358.

Slama, M. (2017). A subtle economy of time: Social media and the transformation of Indonesia's Islamic preacher economy. Economic Anthropology, 4(1), 94-106. https:// doi.org/10.1002/sea2.12075

Smith-Hefner, N. J. (2020). Satan in the Mall: Leisure and Consumption in Java' s New Muslim Middle Class. In R. G. W. Catherine V. Yeh, Eugenio Menegon and Robert P. Weller (Ed.), Testing the Margins of Leisure Case Studies on China, Japan, and Indonesia (pp. 153-180). Heidelberg University Publishing. https://doi.org/ https://doi.org/10.17885/heiup.550

Techinasia.com. (2015). Apa itu bisnis startup? Dan bagaimana perkembangannya? Techinasia.Com. http:// id.techinasia.com/talk/apa-ibu-bisnis-startup-danbagaimana-perkembangannya

Thrift, N. (2003). The Rise of Soft Capitalism. In A. Herod, G. Ó. Tuathail, M.Roberts, \& Susan (Eds.), An Unruly World?Globalization, Governance and Geography (pp. 25-71). Routledge.

Tokopedia.com. (2020).Zakat Fitrah. Tokopedia.Com. https:// www.tokopedia.com/s/zakat-fitrah

Wahyuni, T. (2019). Aktor non-negara dalam filantropi Islam di Indonesia: Kontestasi dan Kolaborasi. UIN Sunan Kalijaga.

Wardani, A. S. (2021). Baznas dan Gopay Kolaborasi Maksimalkan Penerimaan Zakat Digital. Liputan6.Com. https://www.liputan6.com/tekno/read/4540831/ baznas-dan-gopay-kolaborasi-maksimalkanpenerimaan-zakat-digital 